\title{
Energy Use Patterns And Regionalized Energy Use Coefficients For State And Local Governments \#
}

\author{
Gaines H. Liner*
}

\section{INTRODUCTION}

The use of energy by the various segments of society is taking on progressively increasing importance in natural resource planning. Although much emphasis is given to reducing wastes in the private sector, conservation measures necessarily apply to the public sector as well. Perhaps more emphasis should be given to reducing natural resource waste in the public sector to compensate for the absence of the "forces of the market place."

Hopefully, the following discussion will adequately identify the areas of intense energy use by state and local governments disaggregated to the state level. No attempt will be made, however, to suggest conservation measures needed to accomplish more equitable energy resource utilization. Although, such a study would be a logical continuation of this discussion.

In the areas of energy utilization, state and local governments (henceforth referred to as $S \& \mathrm{~L}$ ) account for about 44 percent of the total energy used by the public administration sector. ${ }^{1}$ Though these uses account for a relatively small percentage of the total energy consumed in the United States each year, they are, nevertheless, important to those individual S \& L authorities making purchases. Congress had recognized the importance of public energy use through Public Law 93-275, May $7,1974,{ }^{6}$ by giving the Federal Energy Administration (now a part of the Department of Energy) the responsibility for evaluating the probable impacts of proposed federal energy price changes on $\mathrm{S} \& \mathrm{~L}$.

The objectives of this paper are threefold: first, to construct an algorithm to disaggregate national level energy use per dollar of purchases coefficients to the state level; second, to compare the relative energy intensities of the S \& L by six types of energy; and, third, to suggest a procedure to estimate fiscal impacts of assumed energy price changes on $\mathrm{S}$ \& L by states.

\footnotetext{
\#The initial work on this study commenced while the author was on leave with the Federal Energy Administration (now Department of Energy). Additional financial support was made available at the University of North Carolina at Charlotte through Wachovia Grant Funds. Any findings, views, and conclusions presented herein are those of the author and do not necessarily reflect the views of the Department of Energy. The University of North Carolina at Charlotte, or Wachovia Bank and Trust Company.

*Associate Professor, Department of Economics, University of North Carolina at Charlotte.
} 
Studies of energy use involving S \& L have been presented by a number of people.* Most of these and other studies have dealt with energy uses by $\mathrm{S} \& \mathrm{~L}$ using input-output analysis. To appreciate the impacts of proposed federal energy policy changes on $\mathrm{S} \& \mathrm{~L}$ by states and regions, it is sine qua non that state level energy use coefficients be used. They are also useful in looking at the distributional aspects of income changes due to energy policy changes.

The importance of this study stems from the fact that it is probably the only study which provides estimates of energy use by $\mathrm{S} \& \mathrm{~L}$ in all states. Additionally, these estimates are all based on a consistent set of assumptions, and a procedure is given to estimate the energy coefficients (intensities per dollar of purchases) for $\mathrm{S} \& \mathrm{~L}$ in each state. These coefficients allow comparisons of relative energy intensities of $\mathrm{S} \& \mathrm{~L}$ in states and by regions. From these coefficients one can readily study the probable fiscal impacts of proposed federal energy policy changes on $\mathrm{S} \& \mathrm{~L}$ in the regions.

\section{METHODOLOGY}

This study regionalizes national level energy use coefficients (btu's per dollar of purchases) computed by Lee and Bingham ${ }^{5}$ using a revised form of the Department of Commerce's 1967 input-output table of the United States. Input-output coefficients from other studies could probably be used, but the ones used here are compatible with other energy data that are available and used in this algorithm.

Energy use per dollar of purchases coefficients for six categories of fuels are disaggregated by first estimating energy deliveries directly to $\mathrm{S} \& \mathrm{~L}$ at the state level.

\subsection{Estimates of Direct Energy Use}

Since primary and secondary data relating to direct and indirect energy use by $\mathrm{S} \& \mathrm{~L}$ at the state level are not available in a compatible and useable format, this approach uses proxy variables to produce estimates of direct energy use. A "bridge" is first constructed to estimate direct energy use, $\mathrm{D}_{i \mathrm{j}}{ }^{\prime}$, from state level commercial energy use estimates compiled by the Federal Energy Administration. ${ }^{2}$ The commercial sector energy use estimates, $\mathrm{D}_{\mathrm{ij}}^{\mathrm{c}}$, include those uses by $\mathrm{S} \& \mathrm{~L}$, but unfortunately the $\mathrm{S} \& \mathrm{~L}$ uses are not reported separately. The commercial sector estimates represent the following industries at the two-digit SIC code level: Division F, wholesale trade $(50,51)$; Division $\mathrm{G}$, retail trade (52-59); Division $\mathrm{H}$, finance, insurance, and real estate (60-67); Division I, services (70-89), excluding private households (88); and Division J. public administration (91-96).

Data for 1967 is used to insure compatibility with the national coefficients. More recent data are desirable, but compatible national level input-output energy data were not available.

Direct energy use estimates are produced by the following equation: 
(1) $\mathrm{D}_{\mathrm{ij}}^{\prime}=\mathrm{D}_{\mathrm{ij}}^{\mathrm{c}}$

$$
\left\{\left(\frac{e_{i}}{e_{i}+E_{i}+G_{i}}\right) /\left(\frac{\Sigma e_{i}}{\Sigma\left(e_{i}+E_{i}+G_{i}\right)}\right)\right\} \quad W_{j}
$$

where $\mathrm{D}_{\mathrm{ij}}^{i}=$ unadjusted estimates of direct energy use by $\mathrm{S} \& \mathrm{~L}$ for state $\mathrm{i}$ and fuel $\mathrm{j}$,

$$
\begin{aligned}
\mathrm{D}_{\mathrm{ij}}^{\mathrm{c}}= & \text { energy j used directly in state } \mathrm{i} \text { by the commercial } \\
& \text { sector including public administration, } \\
\mathrm{e}_{\mathrm{i}}= & \text { employment in } \mathrm{S} \& \mathrm{~L} \text { in state } \mathrm{i}, \\
\mathrm{E}_{\mathrm{i}}= & \text { employment in the commercial sector not includ- } \\
& \text { ing any of public administration, } \\
\mathrm{G}_{\mathrm{i}}= & \text { employment in public administration not includ- } \\
& \text { ing } \mathrm{S} \& \mathrm{~L}, \\
\mathrm{~W}_{\mathrm{j}}= & \text { fraction of directly used energy in the commercial } \\
& \text { sector accounted for by } \mathrm{S} \& \mathrm{~L} \text { only, at the national } \\
& \text { level. }
\end{aligned}
$$

If $\mathrm{S} \& \mathrm{~L}$ in state i represents a higher (lower) proportion of the total employment in the commercial sector in state $\mathrm{i}$ than is true for the total United States, then more (less) fuel is allocated to $\mathrm{S} \& \mathrm{~L}$ on the basis of the ratio of the two percentages. The $\mathrm{W}_{\mathrm{j}}$ is taken from the input-output study for the total economy by Bingham, ${ }^{1}$ which is methodologically compatible with the Lee and Bingham study. The employment data are taken from the Compendium of Public Employment ${ }^{7}$ and County Business Patterns. ${ }^{9}$ The employment ratios are used to allocate fuels to $\mathrm{S} \& \mathrm{~L}$ on the basis of the assumption that most of these fuels except for the Gasoline and Other Oils category are used primarily for space heating or water heating by both $\mathrm{S} \&$ $\mathrm{L}$ and the other users in the commercial sector.

The estimates for $\mathrm{D}_{\mathrm{ij}}^{\mathrm{i}}$ are again adjusted upward or downward according to how the estimated sum, $D_{j}^{\prime}=\sum_{i} D_{i j}^{i}$, compares with the control total, $C_{j}^{t}$, taken from the input-output study by Lee and Bingham. The adjusted direct energy use estimate, $D_{i j}$, is computed as

$$
\text { (3) } \quad D_{\mathrm{ij}}=\mathrm{D}_{\mathrm{ij}}^{1} * \mathrm{~A}_{\mathrm{j}}
$$

This procedure adjusts all estimates of direct energy use upward or downward by the same percentage for each category of fuel. This procedure is based on the assumption that errors in estimates produced in (1) are shared equally on a percent basis among the i states. 


\subsection{Direct Energy Use Coefficients}

The values in (3) are converted to coefficients (btu's/dollar of purchases) by dividing by $\mathrm{P}_{\mathrm{i}}$, the level of purchases for goods and services including energy, thus

$$
N_{i j}^{1}=D_{i j} / P_{i}
$$

The $\mathrm{N}_{\mathrm{ij}}$ represents btu's per dollar of purchases for fuel j by $\mathrm{S} \& \mathrm{~L}$ in state $\mathrm{i}$. Since the $\mathrm{P}_{i}$ data are not compiled directly, proxies are computed by the following technique. Aggregated purchases data, $\mathrm{P} \Delta$, from the Survey of Current Business ${ }^{10}$ are used as a control. To produce estimates of purchases by the "i"th state, the dollar value of expenditures, $\mathrm{P}^{\prime}$, from the Compendium of Public Finances, ${ }^{8}$ for all states is divided into the aggregate value of purchases, $\mathrm{P}^{\Delta}$, and then multiplies by the state level expenditures, $\mathrm{P}_{\mathrm{i}}^{\prime}$.

(5) $\mathrm{P}_{\mathrm{i}}=\frac{\mathrm{P}^{\Delta}}{\mathrm{P}^{\prime}} * \mathrm{P}_{\mathrm{i}}^{\prime}=\frac{\Sigma \mathrm{P}_{\mathrm{i}}}{\Sigma \mathrm{P}_{\mathrm{i}}^{\prime}} * \mathrm{P}_{\mathrm{i}}^{\prime}$

This procedure adjusts expenditures for $\mathrm{S} \& \mathrm{~L}$ in the "i"th state upward or downward by the same percentage as the aggregated purchases value for all states differs from the aggregated expenditures value for all states.

\subsection{Indirect Coefficient of Energy Use}

Since indirect energy use data are not available on a state-by-state basis, estimates are computed using total and direct data. Obviously, state-bystate indirect energy use differs from state-to-state, but since such data are not available, average values are used. The indirect coefficient is expressed as the difference between the total coefficient, $\mathrm{N}_{\mathrm{j}}$, and the aggregate direct coefficient, $\mathrm{N}_{\mathrm{j}}^{1}$, computed from aggregated energy use and purchases data. From (4) summing over $\mathrm{i}$, the aggregated direct coefficient is computed

(6) $\mathrm{N}_{\mathrm{j}}^{1}=\Sigma_{\mathrm{i}} \mathrm{D}_{\mathrm{ij}} / \Sigma_{\mathrm{i}} \mathrm{P}_{\mathrm{i}}=\mathrm{D}_{\mathrm{j}} / \mathrm{P}$

where $\mathrm{P}$ represents the total value of purchases from all states. Now the indirect coefficient, $\mathrm{N}_{\mathrm{j}}^{2}$, can be computed

(7) $\quad \mathrm{N}_{\mathrm{j}}^{2}=\mathrm{N}_{\mathrm{j}}-\mathrm{N}_{\mathrm{j}}^{1}$

where $\mathrm{N}_{\mathrm{j}}$ represents the total coefficient calculated in the study by Lee and Bingham. ${ }^{5}$

\subsection{State Level Energy Use Coefficient}

This coefficient is composed of the sum of (4) and (7) or

(8) $\quad \mathrm{N}_{\mathrm{ij}}=\mathrm{N}_{\mathrm{ij}}^{1}+\mathrm{N}_{\mathrm{j}}^{2}$

which is expressed in btu's per dollar of purchases. Now with (8) it is 
possible to estimate the relative energy intensity of each dollar of purchases made by $\mathrm{S} \& \mathrm{~L}$ in each state.

\subsection{Impacts of Energy Price Changes}

To express the impacts of energy price changes on $\mathrm{S} \& \mathrm{~L}$, the values in (8) are converted from btu's per dollar to standard units of volume per dollar. The conversion ratios for the respective fuels are

\begin{tabular}{cll} 
Symbol & \multicolumn{1}{c}{ Volume Measure } & Btu Measure \\
$j=1$ & one ton of coal & $24.97 \times 10^{6}$ \\
$\mathrm{j}=2$ & one $\mathrm{KWH}$ of electricity & 3,413 \\
$\mathrm{j}=3$ & $1000 \mathrm{ft}^{3}$ of natural gas & $1,032 \times 10^{3}$ \\
$\mathrm{j}=4$ & one bbl of distillate oil & $5.825 \times 10^{6}$ \\
$\mathrm{j}=5$ & one bbl of residual oil & $6.287 \times 10^{6}$ \\
$\mathrm{j}=6$ & one bbl of gasoline and other oils & $5.488 \times 10^{6}$
\end{tabular}

The conversion from btu to volume measures is expressed in (9) as

(9) $\mathrm{V}_{\mathrm{ij}}=\left(\mathrm{N}_{\mathrm{ij}}^{1}+\mathrm{N}_{\mathrm{j}}^{2}\right) / \mathrm{C}_{\mathrm{j}}=\mathrm{V}_{\mathrm{ij}}^{1}+\mathrm{V}_{\mathrm{j}}^{2}$

where $C_{j}$ represents the ratio of btu to standard volume measure for fuel $j$.

The impact on $S \& L$ resulting from a change in the price of fuel $j$ can be expressed as a percentage in dollar value of purchases required to maintain a given level of services. This procedure is based on the assumption that all energy price changes are passed through to the ultimate user and that the elasticity of demand for energy in the short run is zero. To the extent that the elasticity of demand for energy is greater than zero, the estimates of impacts of energy price changes computed by this procedure are overstated. If a longer range period is considered, perhaps the elasticity of demand for energy should be considered.

The symbol $\mathrm{j}$ is now expressed in parentheses to denote that the " $\mathrm{j}$ "th fuel has undergone a price change. The percentage change in dollars of outlays for purchases is thus expressed as $\Delta \mathrm{P}_{\mathrm{i}(\mathrm{j})}$ for state $\mathrm{i}$ when the price of fuel $\mathrm{j}$ is changed.

(10) $\Delta \mathrm{P}_{\mathrm{i}(\mathrm{j})}=\left[\mathrm{V}_{\mathrm{ij}}^{1} * \mathrm{pr}_{\mathrm{i}(\mathrm{j})}+\mathrm{V}_{\mathrm{j}}^{2} * \mathrm{pr}_{\mathrm{i}(\mathrm{j})}^{\propto}\right] * 100$

where $\mathrm{pr}_{i(j)}$ represents the change in price of fuel $\mathrm{j}$ used directly in state $\mathrm{i}$ and $\mathrm{pr}_{\mathrm{i}(\mathrm{j})}^{\mathrm{\alpha}}$ represents the change in price of fuel used indirectly.

\section{RESULTS}

Estimates of direct purchases of energy in the six categories are produced in (1) and listed in Table 1. These estimates in btu's give some idea of 
the value of energy consumed through direct purchases by $\mathrm{S} \& \mathrm{~L}$ in individual states. Blanks in the columns represent either no energy consumption or that the total quantity consumed in one year was less than .05 $\mathrm{x} 10^{12} \mathrm{btu}$ 's (the rough equivalent of 2,000 tons of coal). These estimates are useful for making comparisons of raw purchases, but they fail to give one an appreciation for the relative energy purchases per total dollar outlay for all purchases, expenditures, labor time, etc. Direct energy use per dollar of total purchases of goods and services is computed in (4) and listed in Table 2. These estimates produce more useful comparisons of energy consumption relative to $\mathrm{S} \& \mathrm{~L}$ budgets or ability to purchase. They do give some idea of the relative efficiency with which $S$ \& L use energy directly.

Indirect energy consumption per dollar of outlays for purchases are produced in (7) and listed below. These values represent average values of indirect energy used per dollar of purchases of all goods and services by all $\mathrm{S} \& \mathrm{~L}$ in all states and the District of Columbia. They give some idea of the embodied energy in goods and services purchased by $\mathrm{S} \& \mathrm{~L}$. When expressed in btu's $\$$, the coefficients for the six fuels are: Coal, 4036.79; Electricity, 1950.43; Natural Gas, 7187.12; Distillate Oils, 2948.91; Residual Oils, 1002.80; and Gasoline and Other Oils, 8648.26. The importance of coal and natural gas in the manufacturing of goods is reflected in the high btu value of these fuels embodied in products purchased. The Gasoline and Other Oils category is a catchall category and the importance of gasoline is confounded by the inclusion of the other oils.

The estimates of total energy use by $\mathrm{S} \& \mathrm{~L}$ on a state-by-state basis is produced in (8) and listed in Table 3. These values make it possible to analyze the regional intensities of the total energy use by $\mathrm{S} \& \mathrm{~L}$. Energy use per dollar of purchases is ranked by states for each fuel and for all fuels combined. From the ranks it is apparent that the coefficients reflect the effects of the differing efficiencies of energy use, regional climatic differences, and energy use relative to dollar outlays. It is interesting that the intensity of energy use is more related to the degree of urbanization or concentration of population than to regional location. Energy use intensity for all fuels combined seems to be inversely related to urbanization and population concentration in much the same way that gasoline use per capita is greater in rural areas as opposed to urban areas. The ranking of states in overall energy use does not reflect the ranks associated with the individual fuels due, perhaps, to the relative prices of the fuels and to interfuel competition.

In the interest of energy conservation, it is significant that if the intensity of directly used energy in the 10 highest energy using states had been reduced to that of the median, $12,978 \mathrm{btu}$ 's $\$$, a total of 51.91 trillion btu's (or approximately 2.08 million tons of coal) could have been saved in direct energy purchases. The energy intensity ratios used here for directly used and for indirectly used energy are reasonable good proxies for efficiency in use since purchases are usually directly related to expenditures, tax revenue collections, and incomes generated in the state by those being served. 
For policy planning purposes the impacts of proposed energy price changes, measured as the percentage change required in purchases to maintain services, assuming an energy price elasticity of demand of zero in the short run, can be estimated in equation (10). For example, the estimated percentage change in required outlays (impacts) for 1967 for each state is produced in (10) for the respective fuels. The estimated impacts on the $\mathrm{S} \& \mathrm{~L}$ when energy prices are assumed to be increased everywhere by, say, $\$ 2.22 /$ ton of coal, $\$ .0032 / \mathrm{KWH}$ of electricity, $\$ .135 / 1000 \mathrm{ft}^{3}$ of natural gas, $\$ 1.51 / \mathrm{bbl}$ of distillate oils, $\$ 1.34 / \mathrm{bbl}$ of residual oils, and $\$ 2.77 / \mathrm{bbl}$ of gasoline and other oils, are given in Table 4 . From the ranks of impacts given in parentheses, it is apparent that an energy policy that produced across-the-board price changes for each fuel would not produce equal impacts on S \& L in the states. For some fuels the most heavily impacted S \& $\mathrm{L}$ are in one region and in other cases they are not. From this it is apparent that energy policy makers should be cautious when suggesting programs which have an impact of energy prices.

From Table 4 it is obvious that if energy policy is directed at producing the same percentage impact on all states, then different price changes are called for in different states. To maintain equal impacts, price changes for some states or regions should possibly be several times greater in one state than in another. For example, a price change of $\$ .135 / 1000 \mathrm{ft}^{3}$ for natural gas imposed on all states has about three times the impact on Wyoming, Nebraska, Arkansas, New Mexico, and Montana as it does on Hawaii, Maine, Vermont, New Hampshire, and Connecticut. Similarly, differential price changes for other fuels would be called for to produce equal impacts on all states. Consider the high and low ranked impacts in parentheses for other fuels.

From the differential impacts produced by across-the-board price changes it is abundantly clear that policy makers have a responsibility to be aware of and be concerned with the regional and state level impacts of energy policy changes. Since some states rely more on one fuel than another, due to interfuel competition and fuel availability, any disregard of different energy use patterns by policy makers could make the burden of energy costs more disparate than they now are. 
TABLE 1

Direct Energy Use By State \& Local Governments (Trillions Of BTU's Per Year, 1967)

\begin{tabular}{|c|c|c|c|}
\hline States & Coal & Electricity & N. Gas \\
\hline Alabama & .407 & 1.552 & 8.166 \\
\hline Alaska & .149 & .171 & .801 \\
\hline Arizona & $*$ & 2.066 & 7.415 \\
\hline Arkansas & $*$ & 1.145 & 10.216 \\
\hline California & .039 & 15.570 & 42.784 \\
\hline Colorado & 1.027 & 1.432 & 9.727 \\
\hline Connecticut & .108 & 1.168 & 1.731 \\
\hline Delaware & .042 & .298 & .479 \\
\hline Dist. of Columbia & .143 & .326 & .730 \\
\hline Florida & * & 4.020 & 5.137 \\
\hline Georgia & .711 & 2.320 & 7.503 \\
\hline Hawaii & * & .204 & $*$ \\
\hline Idaho & .947 & .940 & 1.321 \\
\hline Illinois & 12.018 & 5.907 & 34.994 \\
\hline Indiana & 4.096 & 2.195 & 14.734 \\
\hline Iowa & 1.344 & 1.314 & 11.611 \\
\hline Kansas & .049 & 1.610 & 10.689 \\
\hline Kentucky & 2.066 & 1.417 & 8.784 \\
\hline Louisiana & $*$ & 2.774 & 14.996 \\
\hline Maine & .256 & .390 & .074 \\
\hline Maryland & .698 & 1.553 & 4.262 \\
\hline Massachusetts & .523 & 1.709 & 4.789 \\
\hline Michigan & 6.767 & 4.194 & 28.079 \\
\hline Minnesota & 2.458 & 1.148 & 14.752 \\
\hline Mississippi & $*$ & 1.492 & 5.639 \\
\hline Missouri & .547 & 1.757 & 16.723 \\
\hline Montana & .047 & .528 & 4.353 \\
\hline
\end{tabular}




\begin{tabular}{|c|c|c|c|}
\hline Dist. Oils & $\begin{array}{l}\text { Residual } \\
\text { Oils }\end{array}$ & $\begin{array}{l}\text { Gasoline } \\
\text { \& Other }\end{array}$ & Total \\
\hline .025 & .156 & 5.594 & 15.901 \\
\hline .135 & .248 & 1.118 & 2.622 \\
\hline .012 & .021 & 4.240 & 13.753 \\
\hline .027 & * & 4.338 & 15.725 \\
\hline .051 & 2.026 & 18.591 & 79.061 \\
\hline .092 & .489 & 3.319 & 16.087 \\
\hline .888 & 4.171 & 1.669 & 9.735 \\
\hline .025 & .464 & 1.003 & 2.310 \\
\hline .008 & 2.745 & .031 & 3.982 \\
\hline .036 & .503 & 7.773 & 17.469 \\
\hline .023 & 1.382 & 7.210 & 19.150 \\
\hline .004 & .110 & .382 & .700 \\
\hline .489 & .087 & 1.206 & 4.990 \\
\hline 1.133 & 11.400 & 15.094 & 80.547 \\
\hline 1.052 & 1.900 & 8.332 & 32.309 \\
\hline .595 & .233 & 5.267 & 20.364 \\
\hline .069 & .056 & 5.249 & 17.721 \\
\hline .150 & .018 & 4.790 & 17.224 \\
\hline .030 & $*$ & 5.193 & 22.992 \\
\hline .495 & 1.213 & 1.325 & 3.752 \\
\hline .102 & 4.709 & 4.499 & 15.823 \\
\hline 2.267 & 25.384 & 3.690 & 38.362 \\
\hline 1.701 & .894 & 6.607 & 48.242 \\
\hline .956 & .210 & 5.887 & 25.410 \\
\hline .025 & * & 3.869 & 11.026 \\
\hline .365 & 1.548 & 6.854 & 27.793 \\
\hline .083 & .473 & 2.204 & 7.688 \\
\hline
\end{tabular}


TABLE 1 continued

Direct Energy Use By State \& Local Governments (Trillions Of BTU's Per Year, 1967)

\begin{tabular}{|c|c|c|c|}
\hline States & Coal & Electricity & N. Gas \\
\hline Nebraska & .124 & 1.051 & 10.163 \\
\hline Nevada & .097 & .516 & 1.185 \\
\hline New Hampshire & .040 & .216 & .319 \\
\hline New Jersey & 1.322 & 2.876 & 6.248 \\
\hline New Mexico & $*$ & .888 & 7.325 \\
\hline New York & 2.946 & 9.497 & 27.005 \\
\hline N. Carolina & 2.900 & 2.856 & 4.512 \\
\hline N. Dakota & .786 & .383 & 1.674 \\
\hline Ohio & 7.977 & 4.538 & 34.229 \\
\hline Oklahoma & .085 & 1.781 & 9.671 \\
\hline Oregon & .475 & 1.952 & 1.788 \\
\hline Pennsylvania & 12.325 & 3.782 & 17.115 \\
\hline Rhode Island & * & .218 & .638 \\
\hline S. Carolina & 1.276 & 1.499 & 2.472 \\
\hline S. Dakota & .245 & .364 & 3.038 \\
\hline Tennessee & 2.348 & 1.393 & 9.037 \\
\hline Texas & * & 7.574 & 31.600 \\
\hline Utah & .711 & .546 & 1.528 \\
\hline Vermont & .079 & .180 & .068 \\
\hline Virginia & 3.077 & 2.737 & 5.194 \\
\hline Washington & .345 & 3.380 & 3.870 \\
\hline W. Virginia & 1.954 & .815 & 5.797 \\
\hline Wisconsin & 7.849 & 1.867 & 8.461 \\
\hline Wyoming & .114 & .540 & 3.683 \\
\hline Total & 81.517 & 110.649 & 467.109 \\
\hline
\end{tabular}

*Blanks represent energy use of less than $.05 \times 10^{12}$ btu's 


\begin{tabular}{|c|c|c|c|}
\hline Dist. Oils & $\begin{array}{c}\text { Residual } \\
\text { Oils }\end{array}$ & $\begin{array}{l}\text { Gasoline } \\
\text { \& Other }\end{array}$ & Total \\
\hline .153 & .095 & 1.371 & 12.957 \\
\hline .033 & .025 & 1.000 & 2.856 \\
\hline .337 & .579 & .680 & 2.170 \\
\hline 1.400 & 12.059 & 7.882 & 31.788 \\
\hline .017 & .017 & 2.266 & 10.513 \\
\hline 2.732 & 53.387 & 9.180 & 104.746 \\
\hline .114 & 1.233 & 6.683 & 18.298 \\
\hline .297 & .071 & 2.697 & 5.909 \\
\hline .865 & .433 & 11.053 & 59.096 \\
\hline .081 & .016 & 5.988 & 17.622. \\
\hline .339 & 2.821 & 3.307 & 10.683 \\
\hline 1.126 & 10.136 & 11.135 & 55.619 \\
\hline .299 & 1.066 & .984 & 3.205 \\
\hline .039 & .436 & 3.946 & 9.667 \\
\hline .213 & .019 & 1.546 & 5.425 \\
\hline .147 & .051 & 6.305 & 19.282 \\
\hline .085 & .102 & 15.018 & 54.381 \\
\hline .080 & .446 & 1.783 & 5.093 \\
\hline .241 & .182 & .485 & 1.235 \\
\hline .103 & 2.067 & 4.054 & 17.232 \\
\hline .543 & 3.414 & 3.880 & 15.433 \\
\hline .009 & .284 & 1.130 & 9.989 \\
\hline 1.368 & .863 & 5.562 & 25.971 \\
\hline .062 & .374 & 1.470 & 6.242 \\
\hline 21.517 & 150.616 & 244.739 & 1076.147 \\
\hline
\end{tabular}


TABLE 2

\section{Direct Energy Use In BTU's Per Dollar Of Purchases (Ranks In Parentheses)}

\begin{tabular}{|c|c|c|c|}
\hline States & Coal & Electricity & $\begin{array}{c}\text { Natural } \\
\text { Gas }\end{array}$ \\
\hline Alabama & 318.28 & 1213.68 & 6385.88 \\
\hline Alaska & 481.11 & 552.14 & 2586.36 \\
\hline Arizona & $0.00 *$ & 2488.06 & 8929.79 \\
\hline Arkansas & 0.00 & 1717.29 & 15322.15 \\
\hline California & 3.32 & 1323.67 & 3637.23 \\
\hline Colorado & 1013.06 & 1412.56 & 9594.97 \\
\hline Connecticut & 82.80 & 895.51 & 1327.17 \\
\hline Delaware & 136.36 & 967.51 & 1555.16 \\
\hline Dist. of Columbia & 311.86 & 710.96 & 1592.03 \\
\hline Florida & 0.00 & 1663.34 & 2125.52 \\
\hline Georgia & 434.91 & 1419.13 & 4589.54 \\
\hline Hawaii & 0.00 & 434.72 & 0.00 \\
\hline Idaho & 3134.94 & 3111.76 & 4373.02 \\
\hline Illinois & 2789.25 & 1370.95 & 8121.75 \\
\hline Indiana & 2086.67 & 1118.22 & 7506.11 \\
\hline Iowa & 1039.11 & 1015.91 & 8976.98 \\
\hline Kansas & 50.25 & 1651.10 & 10961.89 \\
\hline Kentucky & 1690.45 & 1159.43 & 7187.29 \\
\hline Louisiana & 0.00 & 1626.53 & 8792.86 \\
\hline Maine & 688.23 & 1048.47 & 198.94 \\
\hline Maryland & 431.96 & 961.08 & 2637.56 \\
\hline Massachusetts & 215.54 & 704.33 & 1973.69 \\
\hline Michigan & 1636.84 & 1014.47 & 6791.92 \\
\hline Minnesota & 1329.14 & 620.77 & 7977.00 \\
\hline Mississippi & 0.00 & 1862.41 & 7038.98 \\
\hline Missouri & 312.46 & 1003.65 & 9552.63 \\
\hline Montana & 137.58 & 1545.60 & 12742.42 \\
\hline
\end{tabular}




\begin{tabular}{|c|c|c|c|}
\hline Dist. Oils & $\begin{array}{c}\text { Residual } \\
\text { Oils }\end{array}$ & $\begin{array}{l}\text { Gasoline } \\
\text { \& Other }\end{array}$ & Total \\
\hline 19.55 & 121.99 & 4374.55 & $12,433.9(28)$ \\
\hline 435.90 & 800.77 & 3609.93 & $8,466.2(43)$ \\
\hline 14.45 & 14.45 & 5106.18 & $16,552.7(10)$ \\
\hline 40.50 & 0.00 & 6506.22 & $23,586.1(2)$ \\
\hline 4.34 & 172.24 & 1580.49 & $6,721.3(49)$ \\
\hline 90.75 & 482.36 & 3273.95 & $15,867.4(15)$ \\
\hline 680.83 & 3197.93 & 1279.63 & $7,463.9(47)$ \\
\hline 81.17 & 1506.46 & 3256.42 & $7,503.1(46)$ \\
\hline 17.45 & 5986.48 & 67.61 & $8,686.4(42)$ \\
\hline 14.90 & 208.12 & 3216.20 & $7,228.1(48)$ \\
\hline 14.07 & 845.36 & 4410.31 & $11,713.3(30)$ \\
\hline 8.52 & 234.41 & 814.03 & $1,491.7(51)$ \\
\hline 1618.78 & 288.00 & 3992.33 & $16,518.7(11)$ \\
\hline 262.96 & 2645.82 & 3503.16 & $18,693.7(6)$ \\
\hline 535.93 & 967.94 & 4244.67 & $16,459.4(12)$ \\
\hline 460.02 & 180.14 & 4072.15 & $15,744.2(17)$ \\
\hline 70.76 & 57.43 & 5383.01 & $18,174.2(7)$ \\
\hline 122.73 & 14.73 & 3919.30 & $14,093.8(20)$ \\
\hline $17: 59$ & 0.00 & 3044.90 & $13,481.7(24)$ \\
\hline 1330.75 & 3261.01 & 3562.11 & $10,089.5$ \\
\hline 63.12 & 2914.18 & 2784.22 & $9,792.1(38)$ \\
\hline 934.30 & 10461.51 & 1520.76 & $15,810.0(16)$ \\
\hline 411.45 & 216.25 & 1598.14 & $11,669.0(31)$ \\
\hline 516.95 & 113.56 & 3183.34 & $13,740.6(22)$ \\
\hline 31.21 & 0.00 & 4829.54 & $13,762.1(21)$ \\
\hline 208.50 & 884.26 & 3915.19 & $15,876.5(14)$ \\
\hline 242.96 & 1384.60 & 6451.71 & $22,504.7(3)$ \\
\hline
\end{tabular}


TABLE 2 continued

Direct Energy Use In BTU's Per Dollar Of Purchases

(Ranks In Parentheses)

\begin{tabular}{|c|c|c|c|}
\hline States & Coal & Electricity & $\begin{array}{c}\text { Natural } \\
\text { Gas }\end{array}$ \\
\hline Nebraska & 199.99 & 1695.07 & 16391.05 \\
\hline Nevada & 327.43 & 1741.79 & 4000.03 \\
\hline New Hampshire & 144.46 & 780.10 & 1152.10 \\
\hline New Jersey & 477.17 & 1038.08 & 2255.20 \\
\hline New Mexico & 0.00 & 1683.51 & 13887.06 \\
\hline New York & 273.54 & 881.82 & 2507.49 \\
\hline N. Carolina & 1754.96 & 1728.33 & 2730.48 \\
\hline N. Dakota & 2284.17 & 1113.02 & 4864.76 \\
\hline Ohio & 2052.16 & 1167.45 & 8805.75 \\
\hline Oklahoma & 76.85 & 1610.21 & 8743.58 \\
\hline Oregon & 452.38 & 1859.05 & 1702.86 \\
\hline Pennsylvania & 2773.40 & 851.03 & 3851.26 \\
\hline Rhode Island & 0.00 & 517.92 & 1515.74 \\
\hline S. Carolina & 1677.23 & 1970.35 & 3249.30 \\
\hline S. Dakota & 760.87 & 1130.44 & 9434.79 \\
\hline Tennessee & 1613.31 & 957.13 & 6209.31 \\
\hline Texas & 0.00 & 1902.73 & 7938.50 \\
\hline Utah & 1391.99 & 1068.95 & 2991.50 \\
\hline Vermont & 349.84 & 797.11 & 301.13 \\
\hline Virginia & 1893.35 & 1684.14 & 3195.99 \\
\hline Washington & 206.56 & 2023.66 & 2317.04 \\
\hline West Virginia & 2846.60 & 1187.30 & 8445.12 \\
\hline Wisconsin & 3695.97 & 879.14 & 3984.15 \\
\hline Wyoming & 511.18 & 2421.38 & 16514.68 \\
\hline
\end{tabular}

*Zeros represent total direct purchases of less than $.05 \times 10^{12}$ btu's 


\begin{tabular}{|c|c|c|c|}
\hline Dist. Oils & $\begin{array}{c}\text { Residual } \\
\text { Oils }\end{array}$ & $\begin{array}{l}\text { Gasoline } \\
\text { \& Other }\end{array}$ & Total \\
\hline 246.76 & 153.22 & 2211.17 & $20,897.0$ \\
\hline 111.39 & 84.39 & 3375.56 & $9,640.6(40)$ \\
\hline 1217.10 & 2091.11 & 2455.88 & $7,840.7(44)$ \\
\hline 505.33 & 4352.66 & 2844.99 & $11,473.4(32)$ \\
\hline 32.23 & 32.23 & 4295.98 & $19,930.8(5)$ \\
\hline 253.67 & 4957.14 & 852.39 & $9,726.1$ (39) \\
\hline 68.99 & 746.16 & 4044.28 & $11,073.2$ \\
\hline 863.10 & 206.33 & 7837.66 & $17,169.0(8)$ \\
\hline 222.53 & 111.39 & 2843.49 & $15,202.5(18)$ \\
\hline 73.23 & 14.47 & 5413.77 & $15,931.9(13)$ \\
\hline 322.86 & 2686.67 & 3149.52 & $10,173.3$ \\
\hline 253.38 & 2280.86 & 2505.62 & $12,515.5(27)$ \\
\hline 710.36 & 2532.57 & 2337.76 & $7,614.4(45)$ \\
\hline 51.26 & 573.10 & 5186.79 & $12,708.0(26)$ \\
\hline 661.49 & 59.01 & 4801.25 & $16,847.7(9)$ \\
\hline 101.00 & 35.04 & 4332.16 & $13,247.9(25)$ \\
\hline 21.35 & 25.62 & 3772.80 & $13,661.0$ \\
\hline 156.62 & 873.17 & 3490.74 & $9,972.9(37)$ \\
\hline 1067.25 & 805.97 & 2147.78 & $5,469.1(50)$ \\
\hline 63.38 & 1271.87 & 2494.52 & $10,603.2(34)$ \\
\hline 325.10 & 2044.02 & 2323.02 & $9,239.4(41)$ \\
\hline 13.11 & 413.73 & 1646.19 & $14,551.9(19)$ \\
\hline 644.17 & 406.37 & 2619.06 & $12,228.8(29)$ \\
\hline 278.01 & 1677.03 & 6591.52 & $27,993.6(1)$ \\
\hline
\end{tabular}


TABLE 3

Total Coefficient Of Energy Use In BTU's Per Dollar Of Purchases (Ranks In Parentheses)

\begin{tabular}{|c|c|c|c|}
\hline States & Coal & Electricity & $\begin{array}{c}\text { Natural } \\
\text { Gas }\end{array}$ \\
\hline Alabama & $4355.07(29)$ & $3164.11(24)$ & $13572.99(23)$ \\
\hline Alaska & $4517.90(22)$ & $2502.58(49)$ & $9773.48(37)$ \\
\hline Arizona & $4036.79(51)$ & $4438.49(2)$ & $16116.91(11)$ \\
\hline Arkansas & $4036.79(50)$ & $3667.73(11)$ & $22509.27(3)$ \\
\hline California & $4040.11(42)$ & $3274.10(23)$ & $10824.35(31)$ \\
\hline Colorado & $5049.85(18)$ & $3363.00(21)$ & $16782.09(7)$ \\
\hline Connecticut & $4119.59(39)$ & $2845.94(40)$ & $8514.29(47)$ \\
\hline Delaware & $4173.15(38)$ & 2917.94(37) & $8742.28(45)$ \\
\hline Dist. of Columbia & $4348.65(31)$ & $2661.40(46)$ & $8779.15(44)$ \\
\hline Florida & $4036.79(49)$ & $3613.77(15)$ & $9312.63(41)$ \\
\hline Georgia & $4471.70(25)$ & $3369.56(20)$ & $1176.66(26)$ \\
\hline Hawaii & $4036.79(48)$ & $2385.15(51)$ & $7187.12(51)$ \\
\hline Idaho & $7171.73(2)$ & $5062.20(1)$ & $11560.14(27)$ \\
\hline Illinois & $6826.04(4)$ & $3321.39(22)$ & $15308.87(16)$ \\
\hline Indiana & $6123.46(7)$ & $3068.66(29)$ & $14693.23(19)$ \\
\hline Iowa & $5075.90(17)$ & $2966.34(34)$ & $16164.10(10)$ \\
\hline Kansas & $4087.04(41)$ & $3601.54(16)$ & $18149.01(6)$ \\
\hline Kentucky & $5727.24(11)$ & $3109.86(27)$ & $14374.41(20)$ \\
\hline Louisiana & $4036.79(47)$ & $3576.96(17)$ & $15979.98(13)$ \\
\hline Maine & $4725.02(20)$ & $2998.90(32)$ & $7386.06(50)$ \\
\hline Maryland & $4468.75(26)$ & $2911.51(38)$ & $9824.67(36)$ \\
\hline Massachusetts & $4252.33(33)$ & $2654.76(47)$ & $9160.81(42)$ \\
\hline Michigan & $5673.63(13)$ & $2964.90(35)$ & $13979.03(22)$ \\
\hline Minnesota & $5365.93(16)$ & $2571.20(48)$ & $15164.11(17)$ \\
\hline Mississippi & $4036.79(46)$ & $3812.85(7)$ & $14226.10(21)$ \\
\hline Missouri & $4349.25(30)$ & $2954.08(36)$ & $16739.75(8)$ \\
\hline Montana & $4174.37(37)$ & $3496.03(19)$ & $19929.54(5)$ \\
\hline
\end{tabular}




\begin{tabular}{|c|c|c|c|}
\hline Dist. Oils & $\begin{array}{c}\text { Residual } \\
\text { Oils }\end{array}$ & $\begin{array}{l}\text { Gasoline } \\
\& \text { Other }\end{array}$ & Total \\
\hline $2968.46(43)$ & $1124.79(37)$ & $13022.81(12)$ & $38,208(28)$ \\
\hline $3384.81(15)$ & $1803.57(23)$ & $12258.19(22)$ & $34,241(43)$ \\
\hline $2963.36(47)$ & $1017.25(48)$ & $13754.44(8)$ & $42,327(10)$ \\
\hline $2989.40(39)$ & $1002.80(51)$ & $15154.48(3)$ & $49,360(2)$ \\
\hline $2953.24(51)$ & $1175.03(35)$ & $10228.76(46)$ & $32,496(49)$ \\
\hline $3039.66(31)$ & $1485.16(25)$ & $11922.21(27)$ & $41,642(15)$ \\
\hline $3629.74(8)$ & $4200.72(6)$ & $9927.89(48)$ & $33,238(47)$ \\
\hline $3030.07(32)$ & $2509.25(15)$ & $11904.68(28)$ & $33,277(46)$ \\
\hline $2966.35(45)$ & $6989.28(2)$ & $8715.87(51)$ & $34,461(42)$ \\
\hline $2963.80(46)$ & $1210.92(32)$ & $11864.47(29)$ & $33,002(48)$ \\
\hline $2962.98(48)$ & $1848.16(21)$ & $13058.58(11)$ & $37,488(30)$ \\
\hline $2957.43(50)$ & $1237.20(30)$ & $9462.29(50)$ & $27,266(51)$ \\
\hline $4567.69(1)$ & $1290.80(29)$ & $12640.59(18)$ & $42,293(11)$ \\
\hline $3211.86(20)$ & $3648.62(9)$ & $12151.43(24)$ & $44,468(6)$ \\
\hline $3484.84(11)$ & $1970.73(18)$ & $12892.93(15)$ & $42,234(12)$ \\
\hline $3408.93(14)$ & $1182.94(34)$ & $12720.41(16)$ & $41,519(17)$ \\
\hline $3019.67(34)$ & $1060.22(42)$ & $14031.27(6)$ & $43,949(7)$ \\
\hline $3071.64(28)$ & $1017.52(46)$ & $12567.56(19)$ & $39,868(20)$ \\
\hline $2966.50(44)$ & $1002.80(50)$ & $11693.16(32)$ & $39,256,(24)$ \\
\hline $4279.66(2)$ & $4263.81(5)$ & $12210.38(23)$ & $35,864(36)$ \\
\hline $3012.03(37)$ & $3916.98(7)$ & $11432.49(35)$ & $35,566(38)$ \\
\hline $3883.21(5)$ & $1464.31(1)$ & $10169.02(47)$ & $41,584(16)$ \\
\hline $3360.35(16)$ & $1219.04(31)$ & $10246.40(45)$ & $37,443(31)$ \\
\hline $3465.85(12)$ & $1116.35(38)$ & $11831.60(30)$ & $39,515(22)$ \\
\hline $2980.11(41)$ & $1002.80(49)$ & $13477.81(9)$ & $39,536(21)$ \\
\hline $3157.40(26)$ & $1887.05(19)$ & $12563.45(20)$ & $41,651(14)$ \\
\hline $3191.87(24)$ & $2387.40(16)$ & $15099.97(4)$ & $48,279(3)$ \\
\hline
\end{tabular}


TABLE 3 continued

Total Coefficient Of Energy Use In BTU's Per Dollar Of Purchases (Ranks In Parentheses)

\begin{tabular}{lllc}
\hline \multicolumn{1}{c}{ States } & Coal & Electricity & $\begin{array}{c}\text { Natural } \\
\text { Gas }\end{array}$ \\
\hline Nebraska & $4236.78(35)$ & $3645.50(12)$ & $23578.17(2)$ \\
Nevada & $4364.22(28)$ & $3692.22(9)$ & $11187.15(28)$ \\
New Hampshire & $4181.25(36)$ & $2730.54(45)$ & $8339.21(48)$ \\
New Jersey & $4513.96(23)$ & $2988.52(33)$ & $9442.32(40)$ \\
New Mexico & $4036.79(45)$ & $3633.94(14)$ & $21074.18(4)$ \\
New York & $4310.33(32)$ & $2832.26(41)$ & $9694.61(38)$ \\
N. Carolina & $5791.75(10)$ & $3678.77(10)$ & $9917.60(35)$ \\
N. Dakota & $6320.96(6)$ & $3063.46(30)$ & $12051.87(25)$ \\
Ohio & $6088.95(8)$ & $3117.88(26)$ & $15992.87(12)$ \\
Oklahoma & $4113.64(40)$ & $3560.64(18)$ & $15930.70(14)$ \\
Oregon & $4489.17(24)$ & $3809.48(8)$ & $8889.98(43)$ \\
Pennsylvania & $6810.19(5)$ & $2801.47(43)$ & $11038.38(30)$ \\
Rhode Island & $4036.79(44)$ & $2468.35(50)$ & $8702.86(46)$ \\
S. Carolina & $5714.02(12)$ & $3920.78(5)$ & $10436.42(32)$ \\
S. Dakota & $4794.66(19)$ & $3080.87(28)$ & $16621.91(9)$ \\
Tennessee & $5650.10(14)$ & $2907.56(37)$ & $13396.43(24)$ \\
Texas & $4036.79(43)$ & $3853.16(6)$ & $15125.62(18)$ \\
Utah & $5428.78(15)$ & $3019.39(31)$ & $10178.62(34)$ \\
Vermont & $4386.63(27)$ & $2747.55(44)$ & $7488.25(49)$ \\
Virginia & $5930.14(9)$ & $3634.57(15)$ & $10383.11(33)$ \\
Washington & $4243.35(34)$ & $3974.10(4)$ & $9504.15(39)$ \\
West Virginia & $6883.39(3)$ & $3137.73(25)$ & $15632.24(15)$ \\
Wisconsin & $7732.76(1)$ & $2829.57(42)$ & $11171.27(29)$ \\
Wyoming & $4547.97(21)$ & $4371.81(3)$ & $23701.80(1)$ \\
\hline & & & \\
\hline & & & \\
\hline
\end{tabular}




\begin{tabular}{llll}
\hline \multicolumn{1}{c}{ Dist. Oils } & $\begin{array}{c}\text { Residual } \\
\text { Oils }\end{array}$ & $\begin{array}{c}\text { Gasoline } \\
\text { \& Other }\end{array}$ & Total \\
\hline $3195.67(23)$ & $1156.01(36)$ & $10859.43(42)$ & $46,671(4)$ \\
$3060.30(29)$ & $1087.18(40)$ & $12023.82(26)$ & $35,415(40)$ \\
$4166.01(3)$ & $3093.90(12)$ & $11104.14(39)$ & $33,615(44)$ \\
$3454.23(13)$ & $5355.46(4)$ & $11493.25(33)$ & $37,248(32)$ \\
$2981.14(40)$ & $1035.02(44)$ & $12944.25(14)$ & $45,705(5)$ \\
$3202.58(21)$ & $5959.93(3)$ & $9500.65(49)$ & $35,500(39)$ \\
$3017.89(35)$ & $1748.96(24)$ & $12692.54(17)$ & $36,848(33)$ \\
$3812.01(6)$ & $1209.13(33)$ & $16485.93(1)$ & $42,943(8)$ \\
$3171.44(25)$ & $1114.19(39)$ & $11491.76(34)$ & $40,977(18)$ \\
$3022.14(33)$ & $1017.26(47)$ & $14062.03(5)$ & $41,706(13)$ \\
$3271.76(18)$ & $3689.46(8)$ & $11797.79(31)$ & $35,948(35)$ \\
$3202.28(22)$ & $3283.62(11)$ & $11153.89(37)$ & $38,290(27)$ \\
$3659.26(7)$ & $3535.37(10)$ & $10986.02(40)$ & $33,389(45)$ \\
$3000.17(38)$ & $1575.89(25)$ & $13835.05(7)$ & $38,482(26)$ \\
$3610.40(9)$ & $1061.80(41)$ & $13449.51(10)$ & $42,622(9)$ \\
$3049.91(30)$ & $1037.84(43)$ & $12980.42(13)$ & $39,022(25)$ \\
$2970.26(42)$ & $1028.42(45)$ & $12421.06(21)$ & $39,435(23)$ \\
$3105.53(27)$ & $1875.97(20)$ & $12139.00(25)$ & $35,747(37)$ \\
$4016.15(4)$ & $1808.77(22)$ & $10796.04(43)$ & $31,243(50)$ \\
$3012.29(36)$ & $2274.67(17)$ & $11142.78(38)$ & $36,378(34)$ \\
$3274.01(17)$ & $3046.82(13)$ & $10971.29(41)$ & $35,014(41)$ \\
$2962.02(49)$ & $1416.53(27)$ & $10294.46(44)$ & $40,326(19)$ \\
$3593.08(10)$ & $1409.17(28)$ & $11267.32(36)$ & $38,003(29)$ \\
$3226.92(19)$ & $2679.82(14)$ & $15239.79(2)$ & $53,768(1)$ \\
\hline
\end{tabular}


TABLE 4

Fiscal Impact Of Energy Price Change On Purchases (\% Change)*

\begin{tabular}{|c|c|c|c|}
\hline & Coal & Electricity & $\begin{array}{l}\text { Natural } \\
\text { Gas }\end{array}$ \\
\hline $\begin{array}{l}\text { Assumed Price } \\
\text { Change }\end{array}$ & $\frac{\$ 2.22}{\text { ton }}$ & $\frac{\$ .0032}{\text { KWH }}$ & $\frac{\$ .135}{\mathrm{Kft}^{3}}$ \\
\hline \multicolumn{4}{|c|}{ (Ranks In Parentheses) } \\
\hline Alabama & 38.72 & 296.66 & 177.55 \\
\hline Alaska & 40.17 & $234.64(49)$ & 127.85 \\
\hline Arizona & $35.89(51)$ & $416.15(2)$ & 210.83 \\
\hline Arkansas & $35.89(50)$ & 343.88 & $294.45(3)$ \\
\hline California & 35.92 & 306.98 & 141.60 \\
\hline Colorado & 44.90 & 315.31 & 219.53 \\
\hline Connecticut & 36.63 & 266.83 & $111.38(47)$ \\
\hline Delaware & 37.10 & 273.58 & 114.36 \\
\hline Dist. of Columbia & 38.66 & 249.53 & 114.84 \\
\hline Florida & $35.89(49)$ & 338.82 & 121.82 \\
\hline Georgia & 39.76 & 315.93 & 154.06 \\
\hline Hawaii & $35.89(48)$ & $223.63(51)$ & $94.02(51)$ \\
\hline Idaho & $63.76(2)$ & $474.63(1)$ & 151.22 \\
\hline Illinois & $60.69(4)$ & 311.41 & 200.26 \\
\hline Indiana & 54.44 & 287.71 & 192.21 \\
\hline Iowa & 45.13 & 278.12 & 211.45 \\
\hline Kansas & 36.34 & 337.68 & 237.41 \\
\hline Kentucky & 50.92 & 291.58 & 188.04 \\
\hline Louisiana & $35.89(47)$ & 335.37 & 209.04 \\
\hline Maine & 42.01 & 281.17 & $96.62(50)$ \\
\hline Maryland & 39.73 & 272.98 & 128.52 \\
\hline Massachusetts & 37.81 & $248.91(47)$ & 119.84 \\
\hline Michigan & 50.44 & 277.99 & 182.87 \\
\hline Minnesota & 47.71 & $241.07(48)$ & 198.37 \\
\hline Mississippi & 35.89 & 357.49 & 186.10 \\
\hline
\end{tabular}




\begin{tabular}{|c|c|c|}
\hline Dist. Oils & $\begin{array}{l}\text { Residual } \\
\text { Oils }\end{array}$ & $\begin{array}{l}\text { Gasoline And } \\
\text { Other Oils }\end{array}$ \\
\hline$\frac{\$ 1.51}{b b l}$ & $\frac{\$ 1.34}{\text { bbl }}$ & $\frac{\$ 2.77}{b b l}$ \\
\hline 76.95 & 23.97 & 657.31 \\
\hline 87.74 & 38.44 & 618.72 \\
\hline $76.82(47)$ & $21.68(47)$ & 694.24 \\
\hline 77.49 & $21.37(51)$ & $764.90(3)$ \\
\hline $76.56(51)$ & 25.04 & 516.28 \\
\hline 78.80 & 31.65 & 601.76 \\
\hline 94.09 & 89.53 & $501.10(49)$ \\
\hline 78.55 & 53.48 & 600.87 \\
\hline 76.90 & $148.97(2)$ & $439.92(51)$ \\
\hline 76.83 & 25.81 & 598.84 \\
\hline $76.81(48)$ & 39.39 & 659.12 \\
\hline $76.66(50)$ & 26.37 & $477.60(50)$ \\
\hline $118.41(1)$ & 27.51 & 638.02 \\
\hline 83.26 & 77.77 & 613.33 \\
\hline 90.34 & 42.00 & 650.75 \\
\hline 88.37 & 25.21 & 642.05 \\
\hline 78.28 & 22.60 & $708.21(6)$ \\
\hline 79.63 & 21.69 & 634.33 \\
\hline 76.90 & $21.37(50)$ & 590.20 \\
\hline $110.94(2)$ & $90.88(5)$ & 616.30 \\
\hline 78.08 & 83.49 & 577.04 \\
\hline $100.66(5)$ & $244.35(1)$ & $513.27(44)$ \\
\hline 87.11 & 25.98 & 517.17 \\
\hline 89.84 & 23.79 & 597.19 \\
\hline 77.25 & $21.37(49)$ & 680.28 \\
\hline
\end{tabular}


TABLE 4 continued

Fiscal Impact Of Energy Price Change On Purchases (\% Change)

\begin{tabular}{|c|c|c|c|}
\hline & Coal & Electricity & $\begin{array}{l}\text { Natural } \\
\text { Gas }\end{array}$ \\
\hline $\begin{array}{l}\text { Assumed Price } \\
\text { Change }\end{array}$ & $\frac{\$ 2.22}{\text { ton }}$ & $\frac{\$ .0032}{\mathrm{KWH}}$ & $\frac{\$ .135}{\mathrm{Kft}^{3}}$ \\
\hline \multicolumn{4}{|c|}{ (Ranks In Parentheses) } \\
\hline Missouri & 38.67 & 276.97 & 218.98 \\
\hline Montana & 37.11 & 327.79 & $260.71(5)$ \\
\hline Nebraska & 37.67 & 341.80 & $308.44(2)$ \\
\hline Nevada & 38.80 & 346.18 & 146.34 \\
\hline New Hampshire & 37.17 & 256.01 & $109.09(48)$ \\
\hline New Jersey & 40.13 & 280.20 & 123.52 \\
\hline New Mexico & 35.89 & 340.72 & $275.68(4)$ \\
\hline New York & 38.32 & 265.55 & 126.82 \\
\hline N. Carolina & 51.49 & 344.92 & 129.74 \\
\hline N. Dakota & 56.20 & 287.23 & 157.66 \\
\hline Ohio & 54.13 & 292.33 & 209.21 \\
\hline Oklahoma & 36.57 & 333.84 & 208.40 \\
\hline Oregon & 39.91 & 357.17 & 116.29 \\
\hline Pennsylvania & $60.55(5)$ & 262.66 & 144.40 \\
\hline Rhode Island & $35.89(44)$ & $231.43(50)$ & $113.85(46)$ \\
\hline S. Carolina & 50.80 & $367.61(5)$ & 136.52 \\
\hline S. Dakota & 42.65 & 288.86 & 217.44 \\
\hline Tennessee & 50.23 & 272.61 & 175.24 \\
\hline Texas & $35.89(43)$ & 361.27 & 197.86 \\
\hline Utah & 48.27 & 283.10 & 133.15 \\
\hline Vermont & 39.00 & 257.61 & $97.96(49)$ \\
\hline Virginia & 52.72 & 340.77 & 135.83 \\
\hline Washington & 37.73 & $372.61(4)$ & 124.33 \\
\hline West Virginia & $61.20(3)$ & 294.19 & 204.49 \\
\hline Wisconsin & $68.75(1)$ & 265.30 & 146.14 \\
\hline Wyoming & 40.43 & $409.90(3)$ & $310.05(1)$ \\
\hline
\end{tabular}




\begin{tabular}{|c|c|c|}
\hline Dist. Oils & $\begin{array}{l}\text { Residual } \\
\text { Oils }\end{array}$ & $\begin{array}{l}\text { Gasoline And } \\
\text { Other Oils }\end{array}$ \\
\hline$\frac{\$ 1.51}{\mathrm{bbl}}$ & $\frac{\$ 1.34}{\mathrm{bbl}}$ & $\frac{\$ 2.77}{\mathrm{bbl}}$ \\
\hline 81.85 & 40.22 & 634.12 \\
\hline 82.74 & 50.88 & $762.15(4)$ \\
\hline 82.84 & 24.64 & 548.12 \\
\hline 79.33 & 23.17 & 606.89 \\
\hline $107.99(3)$ & 65.94 & 560.47 \\
\hline 89.54 & $114.15(4)$ & 580.11 \\
\hline 77.28 & 22.06 & 653.34 \\
\hline 83.02 & $127.03(3)$ & $579.53(35)$ \\
\hline 78.23 & 37.28 & 640.64 \\
\hline 98.82 & 25.77 & 832.11 \\
\hline 82.21 & 23.75 & 580.03 \\
\hline 78.34 & $21.68(47)$ & $709.76(5)$ \\
\hline 84.81 & 78.64 & 595.48 \\
\hline 83.01 & 69.99 & 562.98 \\
\hline 94.86 & 75.35 & 554.51 \\
\hline 77.77 & 33.59 & 698.31 \\
\hline 93.59 & 22.63 & 678.85 \\
\hline 79.06 & 22.12 & 655.17 \\
\hline 77.00 & 21.92 & 626.94 \\
\hline 80.50 & 39.98 & 612.70 \\
\hline $104.11(4)$ & 38.55 & 544.92 \\
\hline 78.09 & 48.48 & 562.42 \\
\hline 84.87 & 64.94 & 553.76 \\
\hline $76.78(49)$ & 30.19 & 519.60 \\
\hline 93.14 & 30.03 & 568.70 \\
\hline 83.65 & 57.12 & $769.21(2)$ \\
\hline
\end{tabular}




\section{REFERENCES}

1. Bingham, Taylor H., et al., Analysis of Materials and Natural Resource Requirements and Residuals Generation of Personal Consumption Expenditure Items, Research Triangle Institute, prepared for the Environmental Protection Agency, February, 1976.

2. Federal Energy Administration, "Sources of the Information on the State/Federal Reporting Forms: Son-of-Strawman," Working Paper 76-WPA-12, April, 1976.

3. Hite, J. C. and David Mulkey, An Economic Analysis of Petroleum Usage in South Carolina, Parts I and II. Clemson University, Clemson, South Carolina, 1974.

4. Knox, Hugh, "Estimating Impacts of Federal Energy Policy on State and Local Governments: A Suggested Approach," Discussion Paper EIA-76-29,
Office of Economic Impact Analysis, Federal Energy Administration, April, 1976.

5. Lee, B. S., and Taylor H. Bingham, The Energy Requirements of State and Local Government Expenditures, Research Triangle Institute, prepared for the Federal Energy Administration, May, 1976.

6. Public Law 93-275, May 7, 1974, 15 U.S.C. 777, Section 18.

7. U.S. Dept. of Commerce, Bureau of Census, Compendium of Public Employment, 1967.

8. Bureau of Census, Compendium of Public Finances, 1967.

9. Bureau of Census, County Business Patterns, 1967.

10. Office of Business Economics, Survey of Current Business, Julv 1969. 